\title{
An Empirical Analysis of the Price Volatility Characteristics of China's Soybean Futures Market Based on ARIMA-GJR- GARCH Model
}

\author{
Yang Xu $\mathbb{D}^{1},{ }^{1}$ Zhihao Xia $\mathbb{D}^{2},{ }^{2}$ Chuanhui Wang $\mathbb{D}^{2},{ }^{2}$ Weifeng Gong ${ }^{\mathbb{D}},{ }^{2,3}$ Xia Liu ${ }^{\mathbb{D}},{ }^{2}$ \\ and Xiaodi Su $\mathbb{D D}^{2}$ \\ ${ }^{1}$ Management College, Ocean University of China, Qingdao 266100, China \\ ${ }^{2}$ School of Economics, Qufu Normal University, Rizhao 276826, China \\ ${ }^{3}$ School of Economics and Management, Nanjing University of Aeronautics and Astronautics, Nanjing 211006, China \\ Correspondence should be addressed to Chuanhui Wang; chhwang001@163.com
}

Received 15 June 2021; Accepted 6 October 2021; Published 5 November 2021

Academic Editor: Niansheng Tang

Copyright ( $\odot 2021$ Yang Xu et al. This is an open access article distributed under the Creative Commons Attribution License, which permits unrestricted use, distribution, and reproduction in any medium, provided the original work is properly cited.

\begin{abstract}
As the main force in the futures market, agricultural product futures occupy an important position in the China's market. Taking the representative soybean futures in Dalian Commodity Futures Market of China as the research object, the relationship between price fluctuation characteristics and trading volume and open position was studied. The empirical results show that the price volatility of China's soybean futures market has a "leverage effect." The trading volume and open interest are divided into expected parts and unexpected parts, which are added to the conditional variance equation. The expected trading volume coefficient is estimated. Also, the estimated value of the expected open interest coefficient is, respectively, smaller than the estimated value of the unexpected trading volume coefficient and the estimated value of the unexpected open interest coefficient. Therefore, the impact of expected trading volume on the price fluctuation of China's soybean futures market is less than that of unexpected trading volume on the price of soybean futures market. This paper adds transaction volume as an information flow to the variance of the conditional equation innovatively and also observes transaction volume as the relationship between conditional variance and price fluctuations.
\end{abstract}

\section{Introduction}

In bulk commodity trade, soybean is one of the agricultural products with large demand in China, and its price fluctuation is more prominent. China's soybean import is at a disadvantage, and China has become the world's largest importer. Due to the further opening of the soybean market, the price fluctuation of domestic soybean futures is affected by many factors at home and abroad, which has aroused wide attention in China. Since 1996, China has become the world's major soybean importer. In order to optimize the soybean supply structure, the Chinese government has implemented the "reduction of corn and the beans" since 2016. With the Sino-US trade frictions intensified in 2018, the United States increased import tariffs by $25 \%$ and import costs rose. Russia and Canada have thrown out olive branches to increase exports to China. In 2019, the Ministry of Agriculture and Rural Affairs decided to implement the Soybean Revitalization Plan and put forward six subsidy policies to support the development of soybean. In 2020, the No. 1 document of the Chinese government central committee pointed out increasing support for high-yielding soybean varieties and the promotion of new agronomic techniques for intercropping corn and soybean. The reason that China imports more soybeans is mainly reflected in the large domestic supply and demand gap, the inadequate genetic modification technology, and low tariffs. China has a high degree of dependence on international imports of soybeans. Therefore, there is a large price fluctuation of China's soybeans. 
The classical theory often assumes that the return is subject to conditional or unconditional normal distribution, so its volatility is stable. However, the return of financial assets has more complex volatility in the actual market transactions. FAMA [1] studies show that although the volatility of financial asset prices is similar in the similar time periods, there is volatility aggregation effect. The change of the return rate appears a form of peak and thick tail, which does not conform to the simple normal distribution. The return rate is more likely to fall in the limit value region, which has high risk. Foster [2] studied the international crude oil pickup market and found that trading volume has a significant positive impact on futures price volatility. Liu and Wei [3] also found that there was a significant positive correlation between trading volume and futures price volatility. Wang et al. [4] used the ARCH (autoregressive conditional heteroscedasticity) model to analyze the price fluctuation of soybean futures daily trading price data from 2006 to 2011. The research shows that the yield of soybean futures has a second-order arch process, and its price fluctuation has volatility clustering, in which trading volume has a positive role in promoting price fluctuation. Tang et al. [5] took soybean futures and wheat futures in agricultural futures as examples to analyze the long-term correlation of futures price fluctuations and found that the agricultural futures market has state continuity and volatility aggregation. Hua and Zhong [6]; Zhou and Qi [7]; and Cai [8], respectively, used daily trading data of high-frequency data to analyze the characteristics of futures price fluctuations from different perspectives when studying different futures. Based on the EGARCH (exponential generalized autoregressive conditional heteroscedasticity) model, Li et al. [9] studied the relationship among the depth, liquidity, and volatility of CSI 300 Index futures market, which showed that stock index futures can improve the structure of capital market and deepen the reform of capital market. In the research on the price fluctuation of China and American soybean futures market, experts and scholars believe that the price of American soybean futures plays a major role in the transmission of information, and there is fluctuation spillover effect between the two markets [10-16]. Macroeconomic regulation and control may affect commodity price volatility, and some studies show that there is volatility spillover effect from energy market to agricultural product market [17-19]. Jiang and Zhang [20] established a stochastic volatility model by using the non-parametric Bayesian method and studied the data characteristics of the SSE 50 Index, so as to provide suggestions for preventing financial risks. Chen et al. [21] predicted the volatility of Brent crude oil futures market by introducing the hidden Markov model. They believed that the pseudo-structure mutation might occur in this state, and they corrected it by using the ICSS (intra-cranial self-stimulation) model to make the results more accurate. Liu et al. [22] conducted modeling and prediction based on three types of high-frequency extreme volatility data, demonstrating the significance and effectiveness of high-frequency data. Dan et al. [23] constructed a copper futures price fluctuation prediction model based on symbolic high-frequency time series, which shows that K-NN (k-nearest neighbors) algorithm is more accurate. Cai and Liao [24] predicted the volatility of the GEM market and measured the risk by constructing the dynamic higher moment realized EGARCH model and improved the prediction accuracy and risk measurement accuracy.

The futures price fluctuates frequently, which can reflect the market information sensitively. Domestic and foreign scholars mostly use daily high-frequency data to analyze the relationship between trading volume and price fluctuation. It is of great significance to change the perspective to analyze the characteristics of futures price fluctuation. In the soybean futures market, most scholars study the impact of volatility agglomeration effect, spillover effect, and information symmetry on volatility, while there are few studies on price volatility using yield to express the degree of price volatility. It is more to take the trading volume as an explanatory variable and add it into the model, but it is less to introduce the conditional variance equation and use the related models to divide the forecast.

In this paper, the soybean futures of Dalian Commodity Exchange will be researched. The trading volume and position as information flow will be innovatively added to the variance of conditional equation. The relationship between trading volume as conditional variance and price fluctuation will be analyzed. The ARIMA-GJR-GARCH combination model will be constructed. The relationship between trading volume and price fluctuation will be studied, and the relationship between open positions and price fluctuation will also be studied. The relationship between trading volume and open positions is mainly divided into expected trading volume and open positions and unexpected trading volume and open positions. The relationship between trading volume and price fluctuations can be analyzed.

\section{Methods}

2.1. The Established Model. In China's soybean futures market, trading volume and open position are two important variables. Trading volume is mainly used to describe the amount of market information, and open position mainly reflects the depth of the market. They can reflect the role of asymmetric information and the activity of market trading. Trading volume and open position can also describe the different responses of speculators to price changes under the condition of information asymmetry. In the futures market, the time series of trading volume and open position are significantly correlated. Therefore, by entering the prediction model, the trading volume and open position are divided into expected and unexpected to forecast.

In the financial market, AR, MA, ARMA, and ARIMA models are usually used to predict the transaction price or volatility of the in-sample and out-of-sample markets. ARMA and ARIMA models are established on the basis of $\mathrm{AR}$ and MA and can be more comprehensively predicted. The paper will choose both expected and unexpected volume and open interest on the fluctuation of prices, which can only be applicable to the stationary time series ARMA model. The model for the seasonal time series has no direct model, so the paper chooses the ARIMA model. 
In order to deeply and comprehensively describe the volatility characteristics of China's soybean futures price, an ARIMA-GJR-GARCH model will be constructed. Taking into account the trading volume and open interest, the relationship between expected and unexpected trading volume and open interest and the price volatility of China's soybean futures will be comprehensively analyzed.

A "leverage effect" of the financial time series often exists. The characteristic of "leverage effect" is that the price fluctuations caused by bad news or negative shocks are greater than the price fluctuations caused by good news or positive shocks. Therefore, an asymmetric ARCH model needs to be established. The trading volume and open interest are divided into expected and unexpected parts, and the ARIMA-GJRGARCH model is constructed to analyze the characteristics of price fluctuations. For such non-stationary and seasonal sequences, a model can be established as follows:

$$
\phi_{p}(L) \Phi_{p}(L)(1-L)^{d}\left(1-L^{S}\right)^{D} y_{t}=\theta_{q}(L) \Theta_{Q}(L) \varepsilon_{t},
$$

where $p$ represents the order of the seasonal autoregressive process SAR; $Q$ represents the order of the seasonal moving average process SMA; $p, q$, respectively, represent the order of the non-seasonal autoregressive process $A R$ and the order of the non-seasonal moving average process MA; $d, Q$, respectively, represent the order of the non-seasonal and seasonal difference of the sequence $y_{t} ; \phi_{p}(L), \Phi_{p}(L)$, respectively, represent the lag operator polynomial of the nonseasonal autoregressive process $\mathrm{AR}$ and the seasonal autoregressive process SAR; $\left(1-L^{d}\right),\left(1-L^{S}\right)^{D}$, respectively, represent the order of the non-seasonal difference and the seasonal difference lag operator of the sequence; $S$ is the step size of the seasonal difference; and $\theta_{q}(L), \Theta_{q}(L)$, respectively, represent the lag operator polynomial of the nonseasonal moving average process $\mathrm{MA}$ and the seasonal autoregressive process SMA.

The constructed model form is as follows:

$$
\begin{aligned}
R_{t}= & \alpha+\sum_{j=1}^{n} \gamma_{j} R_{t-j}+\sum_{j=1}^{n} \pi_{j} \widehat{\sigma}_{t-j}+U_{t} \\
\widehat{\sigma}_{t}= & \delta+\sum_{j=1}^{n} \omega_{j} \widehat{U}_{t-j}+\sum_{k=1}^{m} \mu_{k} A_{k}+\sum_{j=1}^{n} \beta_{j} \widehat{\sigma}_{t-j}+e_{t}, \\
\widehat{\sigma}_{t}= & \alpha+\mu_{1} \mathrm{ETV}_{t}+\mu_{2} \mathrm{UTV}_{t}+\rho_{1} \mathrm{EOI}_{t} \\
& +\rho_{2} \mathrm{UOI}_{t}+\sum_{j=1}^{n} \beta_{j} \widehat{\sigma}_{t-j}+e_{t},
\end{aligned}
$$

where $t$ stands for time; $R_{t}$ is the price return variable on the day $t ; \mathrm{ETV}_{t}$ represents the expected trading volume on the day $t ; \mathrm{UTV}_{t}$ represents the unexpected trading volume on the day $t$; $\mathrm{EOI}_{t}$ is the expected position on day $t$; $\mathrm{UOI}_{t}$ is the unexpected position on day $t$; and $\alpha, \gamma_{j}, \pi_{j}, \delta, \omega_{j}, \mu_{k}$, and $\beta_{j}$ are the coefficients of the relevant variables in the above models.

2.2. Data Collection and Selection. In recent years, China's soybean futures contracts have been active on the Dalian Commodity Exchange, so the paper chooses the soybean futures contract of Dalian Commodity Exchange for research. The volatility of soybean futures market in China is mainly caused by the fluctuation of price and yield rate, so this paper chooses soybean futures market price as the research object. Two problems should be noted in the selection of data. Firstly, unlike the stock market, futures contracts have a continuous time series of stock prices. Futures contracts are discontinuous, which means that they will be liquidated and stopped trading after the future trading date. Secondly, because there are multiple contracts of different delivery months on the same trading day, there will be different trading prices for the same futures product on the same trading day. Because a number of contracts with different delivery months will participate in the trading on the same trading day, the same futures product has different trading prices on the same trading day. Therefore, in the selection of data, both the discontinuity of futures market prices and the price of futures contracts should be taken into account. This paper selects data of Dalian Commodity Exchange, which are from the database of China Stock Market \& Accounting Research Database (CSMAR). In order to make the transaction data more representative and more convincing, the contracts with large settlement price, volume, and position in the transaction contract are selected. If two contracts are included in a day, the contract with large volume of trading volume and large position is selected. The main contract of China's soybean futures market will be constituted according to the above selection. The settlement price of the contract is selected as the transaction data to form a continuous time series. Soybean futures that can be delivered in Dalian Commodity Exchange include soybean No. 1 and soybean No. 2. As a non-genetically modified soybean, soybean No. 1 is a good representative in the study of price fluctuation in Chinese soybean futures market. Therefore, the main contract of soybean No. 1 is selected as the research object. A total of 1219 sample data from December 31, 2014, to December 31, 2019, were selected.

Through logarithmic processing of the settlement price data of China's soybean futures, the return rate series data were obtained and the statistical characteristics were analyzed. The formula for calculating the return rate was as follows:

$$
R_{t}=\ln \frac{P_{t}}{P_{t-1}},
$$

where $R_{t}$ represents the return rate of the day, $P_{t}$ represents the settlement price of the day, and $P_{t-1}$ represents the settlement price of the previous day. Thus, the time series of return rate can be obtained and analyzed.

\section{Empirical Analysis}

\subsection{The Statistical Characteristics of China's Soybean Futures Market}

3.1.1. Statistical Characteristics of Return Rate. Through logarithmic processing of sample data, the basic statistical results are obtained. A linear chart of daily yield fluctuation of China's soybean futures main contract is obtained as shown in Figure 1. 


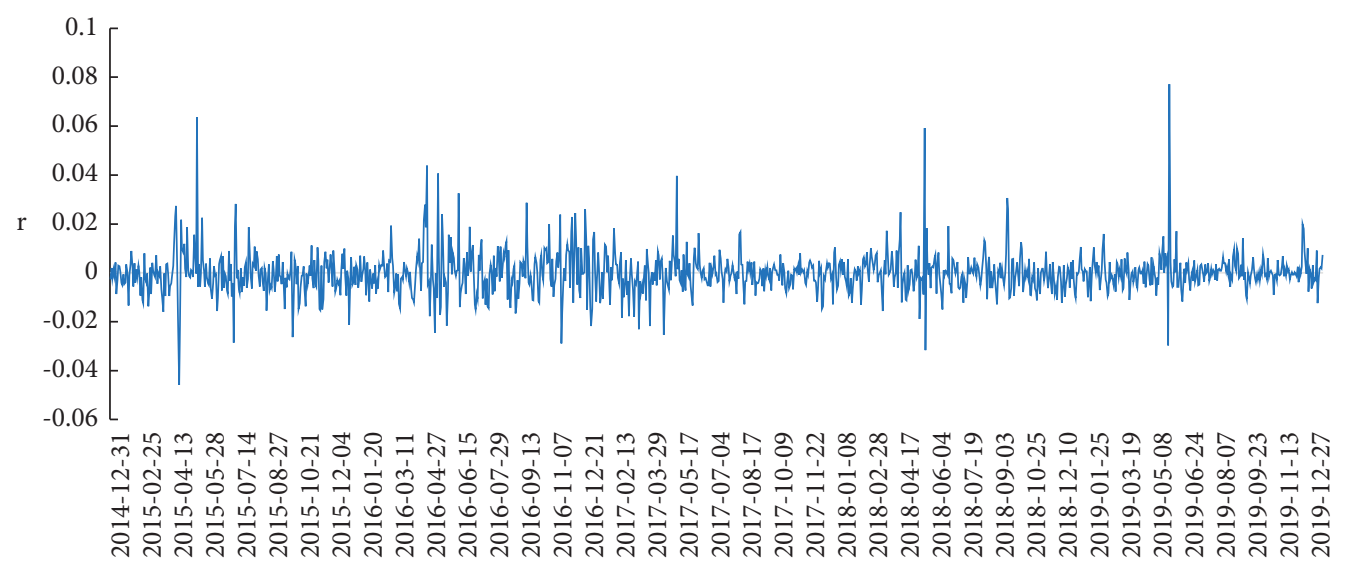

FIGURE 1: Line chart of daily yield fluctuation in Chinese soybean futures market.

TABLE 1: Statistics of the daily return rate sequence of the main continuous contracts of China's soybean futures.

\begin{tabular}{lccccc}
\hline Statistics & Standard deviation & Skewness & Kurtosis & J-B statistics & $p$ value \\
\hline Soybean futures daily return sequence & 0.0086258 & 1.436 & 14.74 & 7417 & $\leq 0.001$ \\
\hline
\end{tabular}

The fluctuation curve of yield rate directly shows the fluctuation degree of yield in China soybean futures market. It can be seen from Figure 1 that the yield sequence of China's soybean futures market has a volatility agglomeration effect, that is, when the volatility is large, it will continue to fluctuate significantly for a period of time, and when the volatility is small for a period of time, it will continue to fluctuate to a smaller extent, and the appearance of volatility agglomeration effect often means that there will be an ARCH effect in the sequence of returns. The emergence of volatility aggregation effect usually represents the $\mathrm{ARCH}$ effect of return series.

The statistical test of the return rate sequence of China's soybean futures market is carried out. Standard deviation is mainly used to reflect the degree of dispersion between individuals of data within the group. Skewness is used as the skewness direction and degree of statistical data. Kurtosis is a statistic used to describe the steep degree of distribution of all values in the overall data. When the data are normally distributed, $K$ equals 3.3. It has a high and thin shape and a thick tail, that is, a sharp peak and a thick tail. Most financial sequences have a sharp peak and a thick tail and are asymmetrically distributed. J-B test statistics are used to test whether the sample sequence obeys normal distribution and study the fluctuation information of return rate. These statistics can best reflect it. The histogram and statistical table of the daily return rate sequence of China's soybean futures continuous contract are shown in Table 1.

From the statistical results in Table 1, it can be seen that the skewness of the daily yield series of China's soybean futures is 1.436. It means that the distribution is skewed to the right relative to the normal distribution, and the rate of return series has a right trailing phenomenon. Kurtosis $K$ equals 14.74, which is greater than the kurtosis value 3 in the normal distribution. It means that the yield series have the characteristics of sharp peaks. Therefore, the yield series of China's soybean futures show the characteristics of sharp peaks and thick tails. The J-B statistic is 7417 , and the corresponding $p$ value is not more than 0.001 , so the null hypothesis should be rejected. It means that the yield series do not obey the standard normal distribution. Considering that financial time series generally have heteroscedasticity, an ARCH model is considered to solve the problem. Therefore, stationarity test and autocorrelation test are also needed for sample time return series.

\subsubsection{Stability Test and Partial Autocorrelation Test of Return}

Rate. Before establishing a model for the rate of return data, it needs to be tested for stationarity, autocorrelation and partial autocorrelation, and ARCH effect. It has been determined that the model to be established subsequently has practical significance.

There is no unit root in the daily yield series of China' soybean futures, which is a stationary series. The autocorrelation and partial autocorrelation tests on the yield data of China's soybean futures market are shown in Table 2.

As can be seen from Table 2, various order sequence correlation values are two times the standard deviation of the set range. It means that China's soybean futures have no obvious yield sequence truncation and trailing phenomenon. Sample sequence lag order autocorrelation and partial autocorrelation coefficient is close to zero. The sample sequence rejects the non-autocorrelation hypothesis under the condition of $5 \%$ confidence level. Therefore, there are autocorrelation and partial autocorrelation in the yield series of China's soybean futures market.

3.1.3. ARCH Effect Test. This paper chooses the Lagrange multiplier test to verify whether the residual series has the ARCH effect. Engle and Granger [25] proposed a Lagrange multiplier test to test whether the residual sequence has the ARCH effect. The ARCH LM test results of the residual sequence are shown in Table 3. 
TABLE 2: The autocorrelation and partial autocorrelation tests on the yield data of China's soybean futures market.

\begin{tabular}{lcccc}
\hline Lag & AC & PAC & $Q$ & Prob $>Q$ \\
\hline 1 & 0.1433 & 0.1433 & 25.077 & $\leq 0.0000$ \\
2 & 0.0361 & 0.0159 & 26.673 & $\leq 0.0000$ \\
3 & 0.0384 & 0.0317 & 28.476 & $\leq 0.0000$ \\
4 & 0.0078 & -0.0026 & 28.55 & $\leq 0.0000$ \\
5 & 0.0401 & 0.0387 & 30.525 & $\leq 0.0000$ \\
6 & 0.0163 & 0.0042 & 30.852 & $\leq 0.0000$ \\
7 & 0.0086 & 0.0041 & 30.942 & 0.0001 \\
8 & 0.0112 & 0.0066 & 31.096 & 0.0001 \\
9 & -0.011 & -0.0147 & 31.245 & 0.0003 \\
10 & 0.0127 & 0.0145 & 31.444 & 0.0005 \\
\hline
\end{tabular}

TABLE 3: The ARCH LM test of residual sequence.

\begin{tabular}{lccc}
\hline Lags $(\mathrm{p})$ & Chi2 & Df & Prob $>$ chi2 \\
\hline 1 & 24.996 & 1 & $\leq 0.001$ \\
2 & 25.293 & 2 & $\leq 0.001$ \\
3 & 26.459 & 3 & $\leq 0.001$ \\
4 & 26.457 & 4 & $\leq 0.001$ \\
5 & 28.198 & 5 & $\leq 0.001$ \\
\hline
\end{tabular}

According to Table 3, it can be obtained that the $p$ value corresponding to each statistic of the residual squared lag of order from 1 to 5 is no more than 0.001 . It means that all the lagging residual squares are jointly significant, and the $p$ value of the $\mathrm{ARCH}$ effect test is also not more than 0.001 , so the null hypothesis is rejected. The residual sequence has conditional heteroscedasticity and has an ARCH effect.

\subsection{Volatility Characteristics of China's Soybean Futures Price.} A volatility curve between trading volume and open interest and yield is drawn, as shown in Figure 2.

According to Figure 2, it can be seen that the volatility of trading volume is relatively large. The range of change between open interest and trading volume is basically the same. The range of change in the rate of return is relatively small.

Firstly, the ARIMA model is used to predict the volume and open interest in the sample. The predictable part is called the expected volume and the open interest, which are recorded as $\mathrm{ETV}_{t}$ and $\mathrm{EOV}_{t}$, respectively. The relative error of the difference between the actual value and the predicted value is called the unexpected transaction. The volume and open interest are recorded as $\mathrm{UTV}_{t}$ and $\mathrm{UOV}_{t}$, respectively. Then, the above two variables are added to the conditional variance equations of the GJR-GARCH $(2,1)$ model to explore the empirical analysis of the impact of soybean futures price fluctuations.

The regression analysis results are shown in Tables 4 and 5 .

As can be seen from Tables 4 and 5, $c$ represents the coefficient of the constant term, which is greater than zero. $\mu_{1}$ represents the estimated value of the expected trading volume coefficient. $\mu_{2}$ represents the estimated value of the unexpected trading volume coefficient. $\rho_{1}$ represents the expected open position coefficient, and $\rho_{2}$ represents the unexpected open position coefficient.

According to Tables 4 and 5, the following conclusions can be drawn.
The estimated value $\mu_{1}$ of expected trading volume coefficient and the estimated value $\mu_{2}$ of unexpected trading volume coefficient are more than 0 , respectively. The results are significant, which indicates that there is a positive correlation between expected trading volume and unexpected trading volume and price fluctuation in China's soybean futures market. The estimated values of the expected position coefficient $\rho_{1}$ and the unexpected position coefficient $\rho_{2}$ are not more than 0.001 , and the results are significant, indicating that there is a negative correlation between the expected position and the unexpected position and the price fluctuation in China's soybean futures market. Increasing a certain number of positions will reduce the impact of price fluctuation caused by the increase of trading volume.

From the perspective of the relationship between current trading volume and open interest, soybean futures price fluctuations have a deeper level. The newly opened trades are far less than the impact of closing trades and handover transactions on price fluctuations from the perspective of trader behavior. Set the marginal impact of current trading volume on price fluctuations as $M_{\mu}$ and the marginal impact of current holdings on price fluctuations as $M_{\rho}$. At the beginning of the new position trading, it has an impact on the current trading volume. The current trading volume will increase, but the change of the current position is uncertain. If the new transaction is a new open position futures contract, then the current trading volume and position will have the same amount of increase. At this time, the impact on the price fluctuation in the soybean futures market is the sum of the marginal impact of the current trading volume on the price fluctuation and the marginal impact of the current position on the price fluctuation, which is recorded as $M_{\mu}+M_{\rho}$. If the new transaction is a soybean futures contract with closed trading units, the impact on the current trading volume and position is that when the trading volume increases by a certain amount, the position will decrease by a certain amount. At this time, the impact on price fluctuation in soybean futures market is the marginal impact of current trading volume on price fluctuation minus the marginal impact of current position on price fluctuation, which is recorded as $M_{\mu}-M_{\rho}$. If the new transaction is to change the number of trading units of soybean futures contract, the impact on the current trading volume and position is that the trading volume will have a certain amount of increase, and the position will remain unchanged. At this time, the impact on the price fluctuation in the soybean futures market is the marginal impact of the current trading volume on the price fluctuation, which is recorded as $M_{\mu}$. In the soybean futures market, there is such a relationship: $M_{\mu}>0, M_{\rho}<0$; then, $M_{\mu}-M_{\rho}>M_{\mu}>M_{\mu}+M_{\rho}$. When the soybean futures market rises unilaterally, the trading parties establish new transactions. The market participants will increase their interests in the new trading contract, so that a large number of funds will enter the new trading futures contract, and the market depth will continue to increase. Thus, it can reduce the impact of current trading volume changes on price fluctuations.

The estimated value of the expected trading volume coefficient $\mu_{1}$ is less than the estimated value of the unexpected trading volume coefficient $\mu_{2}$, and the estimated value 


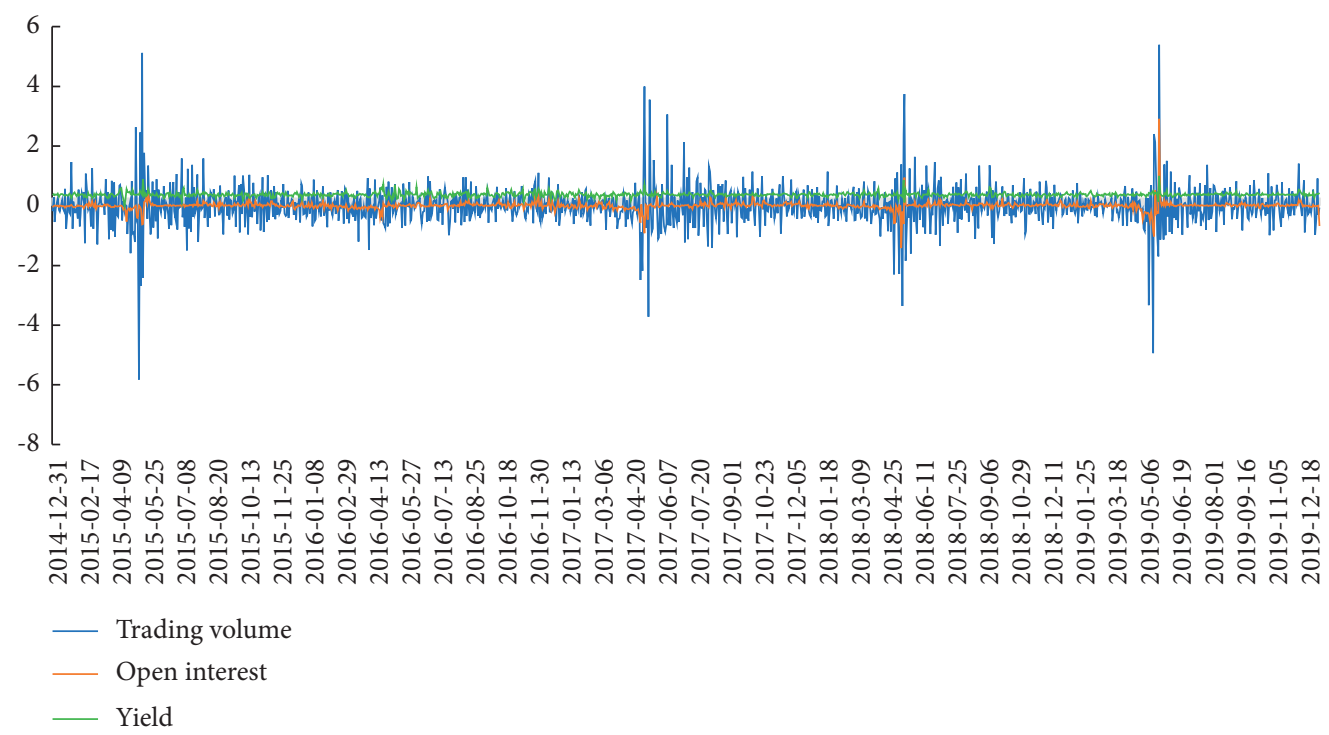

FIgURE 2: The volatility curve of trading volume, open interest, and yield.

of the expected position coefficient $\rho_{1}$ is less than the estimated value of the unexpected trading volume coefficient $\rho_{2}$. Therefore, the impact of the expected trading volume on the price fluctuation of China's soybean futures market is less than the impact of the unexpected trading volume on the price fluctuation of China's soybean futures market. This phenomenon can be explained as follows: in China's soybean futures market, when new information appears, there will be transactions caused by information asymmetry and liquidity demand difference. The emergence of new information will lead to the emergence of transactions to a certain extent. In China's soybean futures market, the expected trading volume and position are not generated by new information, but mainly by market participants through changing liquidity demand or adjusting positions. The unexpected trading volume and position are mainly generated by the arrival of new information in the soybean futures market, which contains more information. Therefore, the impact of unexpected trading volume and position on the price fluctuation of China's soybean futures market is stronger than that of the expected trading volume and position on the price fluctuation of China's soybean futures market.

\subsection{The Influence of Trading Volume and Open Position on} ARIMA-GJR-GARCH Model. The influence of trading volume and open position on ARIMA-GJR-GARCH model is further analyzed. The trading volume is introduced into the conditional variance equation based on the ARIMA-GJRGARCH model as information flow. The results are shown in Table 6.

The coefficient of current trading volume is greater than zero and significant at the significance level of $5 \%$ in Table 6 . It means that there is a positive correlation between trading volume and price volatility. After the current trading volume is added into the conditional variance equation, the GARCH term coefficient changes from the previous 0.9615618 to 0.1830656 , which decreases significantly. The result is still significant at the significance level of $5 \%$, indicating that the GARCH effect in the model is obviously weakened, but the GARCH effect still exists.

However, the coefficient of ARIMA-GJR-GARCH term changed from -0.0453458 to 0.2090938 , and the result was significant at the significance level of $5 \%$. The coefficient changed from negative to positive, indicating that the model no longer had asymmetry after adding volume. It means that volume absorbs part of the persistence and asymmetry of price fluctuations, indicating that volume has a strong ability to explain price fluctuations. In the mixed distribution hypothesis $(\mathrm{MDH})$, there is a positive correlation between the volatility variance of asset prices and information variables after the introduction of information variables. The conditional expected value of trading volume mainly depends on information variables, so there is a positive correlation between trading volume and price volatility in the futures market. Through the empirical analysis of China's soybean futures market, the mixed distribution hypothesis is proved. Adding the current soybean futures trading volume into the model as a substitute index of mixed variables has a strong ability to explain price fluctuations.

Open positions are introduced into the conditional variance equation based on ARIMA-GJR-GARCH model as information flow. The results are shown in Table 7.

In Table 7, the coefficient of open position in the current period is less than zero and significant at the significance level of $5 \%$, indicating that there is a negative correlation between open position and price volatility, and open position has a strong explanatory power on the variance of price volatility. After adding the current open position into the conditional variance equation, the GARCH term coefficient decreases slightly, and the GARCH effect exists. It means that the current open position has little influence on the persistence of soybean futures price volatility, and the volatility variance of soybean futures price still has a strong persistence. The coefficient of ARIMA-GJR-GARCH term changes from -0.0453458 to 0.0158608 , and the result is not 
TABLE 4: The relationship between expected trading volume and open interest and price fluctuations in China's soybean futures market.

\begin{tabular}{lcccccc}
\hline & Coefficient & Standard error & $z$ value & $p$ value & $2.5 \%$ quantile & $97.5 \%$ quantile \\
\hline$C$ & 0.3687882 & 0.0017501 & 214.39 & $\leq 0.001$ & 0.3654168 & 0.3721596 \\
$\mu_{1}$ & 0.9586294 & 0.1421858 & 6.74 & $\leq 0.001$ & 0.6799503 & -1.2373090 \\
$\rho_{1}$ & -15.59571 & 0.7651638 & -20.38 & $\leq 0.001$ & -17.09541 & -14.096020 \\
$\alpha_{1}$ & 0.1640964 & 0.0397881 & 4.12 & $\leq 0.001$ & 0.0861133 & 0.2420796 \\
$\alpha_{2}$ & -0.0977562 & 0.0355365 & -2.75 & 0.006 & -0.1674065 & 0.0281059 \\
$\gamma$ & 0.0745078 & 0.029619 & 2.52 & 0.012 & 0.0164555 & 0.1325600 \\
$\beta_{1}$ & 0.7738417 & 0.025848 & 29.94 & $\leq 0.001$ & 0.7231805 & 0.8245029 \\
\hline
\end{tabular}

TABLE 5: The relationship between unexpected trading volume and open interest and price fluctuations in China's soybean futures market.

\begin{tabular}{lcccccc}
\hline & Coefficient & Standard error & $z$ value & $p$ value & $2.5 \%$ quantile & $97.5 \%$ quantile \\
\hline$c$ & 0.3687889 & 0.0014382 & 256.43 & $\leq 0.001$ & 0.3659701 & 0.3716077 \\
$\mu_{2}$ & 1.681456 & 0.0767077 & 21.92 & $\leq 0.001$ & 1.531108 & 1.831797 \\
$\rho_{2}$ & -1.179658 & 0.1932675 & -6.10 & $\leq 0.001$ & -1.558455 & -0.8008604 \\
$\alpha_{1}$ & 0.1919649 & 0.0284119 & 6.76 & $\leq 0.001$ & 0.1362786 & 0.2476511 \\
$\alpha_{2}$ & -0.004453 & 0.0235912 & -0.19 & 0.850 & -0.0506908 & 0.0417848 \\
$\gamma$ & 0.1492003 & 0.057995 & 2.57 & 0.010 & 0.0355234 & 0.2628773 \\
$\beta_{1}$ & 0.2068837 & 0.0231923 & 8.92 & $\leq 0.001$ & 0.1614275 & 0.2523398 \\
\hline
\end{tabular}

TABLE 6: The relationship between trading volume and China's soybean futures price volatility.

\begin{tabular}{lcccccc}
\hline & & $\alpha_{1}$ & $\beta_{1}$ & $\gamma_{1}$ \\
\hline \multirow{3}{*}{ Untraded model } & Coefficient estimation & 0.4193364 & -0.3562949 & 0.9615618 & -0.0453458 \\
& $Z$ & 13.24 & -10.82 & 153.91 & -5.38 \\
& $P$ & 0.000 & 0.000 & 0.000 & 0.000 \\
\hline \multirow{3}{*}{ Traded model } & Coefficient estimation & 0.2300784 & -0.026109 & 0.1830656 & 0.2090938 & 1.317224 \\
& $Z$ & 7.08 & -1.1 & 6.87 & 3.42 & 15.65 \\
& $P$ & 0.000 & 0.272 & 0.000 & 0.001 \\
\hline
\end{tabular}

TABLE 7: The relationship between open position holding and price fluctuation of China's soybean futures market.

\begin{tabular}{lcccccc}
\hline & & $\alpha_{1}$ & $\alpha_{2}$ & $\beta_{1}$ & $\gamma_{1}$ \\
\hline \multirow{3}{*}{ Untraded model } & Coefficient estimation & 0.4193364 & -0.3562949 & 0.9615618 & -0.0453458 \\
& $Z$ & 13.24 & -10.82 & 153.91 & -5.38 \\
& $P$ & 0.000 & 0.000 & 0.000 & 0.000 \\
Traded model & Coefficient estimation & 0.2467478 & -0.1721645 & 0.8575355 & 0.0158608 & -3.950086 \\
& $Z$ & 7.03 & -5.42 & 51.40 & 0.81 & -20.16 \\
& $P$ & 0.000 & 0.000 & 0.000 & 0.420 & 0.000 \\
\hline
\end{tabular}

significant at the significance level of $5 \%$. The coefficient changes from negative to positive, indicating that the model is no longer asymmetric after the addition of position. Therefore, open position has a strong explanatory power on price fluctuations.

\section{Conclusion}

This paper analyzes the price fluctuation characteristics of China's soybean futures market by constructing an ARIMAGJR-GARCH model and draws the following conclusions:

(1) The price volatility of China's soybean futures is stable. The impact of the previous shock on the variance of the subsequent conditions is long lasting and will act on future volatility for a long time. Therefore, the volatility and market risk are relatively high. The main reason is that China's soybeans are mainly derived from imports and changes in the international political situation will have a huge impact on China's soybean futures market. Secondly, China's soybean futures price fluctuations have a leverage effect. The impact of negative news is greater than the impact of positive news. Exogenous interference will affect China's soybeans. Fluctuations in futures prices have an impact.

(2) In this paper, the current trading volume and position of China's soybean futures contract are added to the conditional variance equation based on ARIMA-GJR-GARCH $(2,1)$ model, respectively, and the relationship between expected and unexpected trading volume and position and price fluctuation is studied. The results show that the estimated value of the expected trading volume coefficient and the estimated value of the expected 
position coefficient are less than the estimated value of the unexpected trading volume coefficient and the estimated value of the unexpected trading volume coefficient, respectively. When the trading volume of the current soybean futures contract increases and the open interest decreases, the impact on the variance of price fluctuations is greater than that of the current increase in trading volume, and the open interest increases or remains unchanged. Therefore, the impact of the expected trading volume on the price fluctuation of China's soybean futures market is less than that of the unexpected trading volume on the price fluctuation of China's soybean futures market. The main reason is that the expression of new information is mainly realized by unexpected trading volume, and new information is an important factor affecting price volatility.

\section{Data Availability}

Previously reported data were used to support this study and are available at https://www.gtarsc.com/.

\section{Conflicts of Interest}

The authors declare that they have no conflicts of interest.

\section{Acknowledgments}

This paper benefited from years of thinking about these issues and discussion with many colleagues related to economics at that time. This research was supported by the Humanities and Social Sciences Youth Foundation of Ministry of Education of China under grant no. 19YJC790128.

\section{References}

[1] FAMA, "Efficient capital markets: a review of theory and empirical work," The Journal of Finance, vol. 25, no. 2, pp. 383-471, 1970.

[2] A. J. Foster, "Volume-volatility relations for crude oil futures markets," Journal of Futures Markets, vol. 15, no. 8, pp. 929-951, 1995.

[3] X. M. Liu and Z. X. Wei, "Discussion on the relationship between trading volume and income volatility in wheat futures market," Financial Theory \& Practice, vol. 11, pp. 87-90, 2011.

[4] X. D. Wang, B. Liu, and Y. Yan, "Fluctuation analysis of China's soybean futures price based on arch model," Journal of Agrotechnical Economics, vol. 12, pp. 73-79, 2013.

[5] Y. W. Tang, G. Chen, and C. H. Zhang, "An empirical research on the long-term correlation of the price volatility of the agricultural products futures markets," Systems Engineering, vol. 12, pp. 79-84, 2005.

[6] R. H. Hua and W. J. Zhong, "An empirical analysis on the dynamic relationship between futures price fluctuation and trading volume and short offer volume in Chinese futures market," The Journal of Quantitative \& Technical Economics, vol. 7, pp. 123-132, 2004.
[7] B. Zhou and Z. Y. Qi, "Empirical research on the volatility in two different stages of Chinese futures markets," Journal of Applied Sport Management, vol. 3, pp. 518-527, 2007.

[8] C. Cai, "Research on the price volatility of major commodity futures in this economic crisis," Financial Theory \& Practice, vol. 2, pp. 64-69, 2010.

[9] J. L. Li, Y. Lei, and S. J. Li, "Market depth, liquidity and volatility: the impact of CSI 300 stock index futures on spot market," Journal of Financial Research, vol. 6, pp. 124-138, 2012.

[10] T. Xia and X. Y. Cheng, "Research on the dynamic relationship between domestic and foreign futures prices and domestic spot prices-_based on the empirical analysis of DCE and CBOT soybean futures markets and domestic soybean markets," Journal of Financial Research, vol. 2, pp. 110-117, 2006.

[11] Y. H. Zhou and L. G. Zou, "Research on the price relationship between China's soybean futures market and international soybean futures market-—an empirical analysis based on VAR model," Journal of Agrotechnical Economics, vol. 1, pp. 55-62, 2007.

[12] X. G. Li and Y. H. Zhou, "Research on volatility spillover effect among Chinese and international soybean future markets," Journal of Technical Economics \& Management, vol. 6, pp. 103-107, 2014.

[13] L. Sun, K. K. Ni, and X. G. Li, "The dynamic correlation of food price between domestic and abroad: based on DCCMGARCH model," Journal of Nanjing Agricultural University (Social Sciences Edition), vol. 14, no. 2, pp. 65-72, 2014.

[14] J. Y. Zheng, "Effects of international genetically modified soybean on China's soybean industry and its futures market," Asia-pacific Economic Review, vol. 5, pp. 39-46, 2015.

[15] H. L. Wang and Y. F. Zhao, "An analysis on price relationship between China and US soybean futures markets: based on structural breaks viewpoint," Journal of China Agricultural University, vol. 21, no. 9, pp. 156-165, 2016.

[16] J. H. Liu, J. H. Tian, Y. B. Wang, and H. Z. Wu, "Volatility spillover effect between Chinese and American soybean futures markets based on variable structure copula function," Soybean Science, vol. 38, no. 3, pp. 469-476, 2019.

[17] X. Du, C. L. Yu, and D. J. Hayes, "Speculation and volatility spillover in the crude oil and agricultural commodity markets: a bayesian analysis," Energy Economics, vol. 33, no. 3, pp. 497-503, 2011.

[18] S. Nazlioglu and U. Soytas, "Oil price agricultural commodity prices and the dollar: a panel co-integration and causality analysis," Energy Economics, vol. 34, no. 4, pp. 1098-1104, 2012.

[19] Q. Ji and Y. Fan, "How does oil price volatility affect nonenergy commodity markets?" Applied Energy, vol. 89, no. 1, pp. 273-280, 2012.

[20] Y. Y. Jiang and B. Zhang, "Non-parameter bayesian stochastic volatility model and its application in the financial markets," Journal of Applied Sport Management, vol. 38, no. 1, pp. 49-61, 2019.

[21] Z. Chen, Y. Lin, D. S. Huang, and Y. X. Chen, "Forecasting of structure breakthrough points in brent crude oil futures market," Journal of Systems \& Management, vol. 28, no. 6, pp. 1095-1105, 2019.

[22] W. Y. Liu, H. Y. Jiang, T. W. Zhang, and W. Chen, "Volatility modeling and forecasting based on high frequency extreme value data," Systems Engineering-Theory \& Practice, vol. 40, no. 12, pp. 3095-3111, 2020.

[23] W. Dan, B. Jbha, and B. Mrza, "Prediction of metal futures price volatility and empirical analysis based on symbolic time 
series of high-frequency," Transactions of Nonferrous Metals Society of China, vol. 30, no. 6, pp. 1707-1716, 2020.

[24] G. H. Cai and Y. Q. Liao, "Dynamic higher moment realized EGARCH model and application based on structural breaks," The Journal of Quantitative \& Technical Economics, vol. 38, no. 1, pp. 157-173, 2021.

[25] R. F. Engle and C. Granger, "Cointegration and error-correction: representation, estimation and testing," Econometrica, vol. 55, no. 2, pp. 251-276, 1987. 